\title{
DETERMINATION OF SELECTED TRACE ELEMENTS IN AIRBORNE AEROSOL PARTICLES USING DIFFERENT SAMPLE PREPARATION*
}

\author{
Janja TURŠIČ ${ }^{1}$, Helena RADIĆ ${ }^{2}$, Miroslav KOVAČEVIĆ ${ }^{3}$, and Marjan VEBER ${ }^{4}$ \\ Environmental Agency of the Republic of Slovenia ${ }^{1}$, National Institute of Chemistry ${ }^{2}$, Lek Pharmaceuticals d.d. ${ }^{3}$, \\ University of Ljubljana, Faculty for Chemistry and Chemical Technology44, Ljubljana, Slovenia
}

Received in March 2008

Accepted in May 2008

\begin{abstract}
Determination of trace element concentrations in atmospheric aerosols is important because of their toxic effects on human health. Additionally, they are now widely used in source apportionment studies. There is a number of methods for sample preparation of ambient particulate matter. One of the most widely used is microwave-assisted digestion of filter-based samples. Since the water-soluble fraction is bioavaliable, the aim of our study was to determine the concentration of selected trace elements $(\mathrm{V}, \mathrm{Cr}, \mathrm{Mn}, \mathrm{Ni}, \mathrm{Cu}, \mathrm{Zn}, \mathrm{As}$, $\mathrm{Cd}, \mathrm{Sb}, \mathrm{Tl}$, and $\mathrm{Pb}$ ) in this fraction and compare it to the amounts obtained by two different microwave digestion procedures - one using a mixture of $\mathrm{H}_{2} \mathrm{O}_{2}$ and $\mathrm{HNO}_{3}$ and the other using a mixture of $\mathrm{HF}, \mathrm{HCl}$, and $\mathrm{HNO}_{3}$. The recoveries of the digestion procedures used were tested on certified reference material (NIST SRM 1648 Urban Particulate Matter). The procedures were applied to filters containing PM ${ }_{10}$ particles collected at an urban background location in Ljubljana, Slovenia. Among the elements analysed, V, Zn, $\mathrm{As}$, and $\mathrm{Cd}$ displayed the highest concentration within the water-soluble fraction, with $\mathrm{Cr}, \mathrm{Ni}, \mathrm{Tl}$ and $\mathrm{Pb}$ displaying the lowest concentrations. The comparison between the two applied digestion procedures showed that $\mathrm{Cr}, \mathrm{Ni}, \mathrm{Sb}$ and $\mathrm{Tl}$ were strongly bound to the sample matrix.
\end{abstract}

KEY WORDS: chemical analysis, digestion, ICP-MS, metals, $P M_{10}$, urban aerosols, water-soluble fraction

Atmospheric particles are generated through a variety of physical and chemical mechanisms, and are emitted into the atmosphere from numerous sources, by combustion, industrial and natural processes. They are involved in many atmospheric processes, and play an important role in reducing visibility, acid deposition, and the balance of radiation in the atmosphere, both directly and indirectly through cloud formation (1). There is a general agreement that airborne particulate matter is associated with adverse effects on human health (2). The concentration and composition of

"This study has partly been presented at the Fifth Croatian Scientific and Professional Assembly "Air Protection '07" held in Zadar, Croatia, on 9-13 October 2007. particles may vary with size, time, and location, and depends strongly on the distance from the source, rate of emission, convective and turbulent diffusive transfer rates, on the efficiency of various removal mechanisms, and on meteorological parameters which affect vertical and horizontal distribution (3-5).

Toxicological studies have frequently implicated metal content (particularly water-soluble metal) as a possible harmful component of particulate matter. In vivo and in vitro studies have shown that metals generate reactive oxygen species, that activate cellular inflammatory response pathways (6). The potentially toxic elements are $\mathrm{As}, \mathrm{Cd}, \mathrm{Cr}, \mathrm{Hg}$, and $\mathrm{Pb}$ (7). Additionally, trace element content in particulate matter is often used in source apportionment studies. 
Metals are released into the atmosphere during combustion of fossil fuels and wood, as well as during high temperature industrial processes and waste incineration. Natural emissions result from a variety of processes acting on crustal minerals, including volcanism, erosion, surface winds, forest fires and ocean evaporation (8).

There are many different methods for sample preparation and chemical analysis of atmospheric particles. Among the non-destructive methods the most widely used are particle-induced X-ray emissions (PIXE), instrumental neutron activation analysis (INAA), and X-ray fluorescence spectrometry (XRF). Since recently, trace metals have also been analysed using inductively coupled plasma / mass spectrometry equipped with laser ablation introduction system (LA) ICP-MS) (9). Destructive analytical procedures include microwave-assisted digestion of filter-based samples, which is the most common method, followed by inductively coupled plasma / mass spectrometry (ICP-MS) or other spectrometric methods such as atomic absorption spectrometry (AAS). The choice of digestion reagents is for determination and characterization of multiple elements in ambient aerosols. Combustion and industrial processes are the primary source of carbonaceous and metallic particles, with soil erosion providing the major source of crustal material. The most abundant secondary constituents are sulphates, nitrates, and different organic compounds. Concentrated $\mathrm{HNO}_{3}$ is usually the first choice because of its strong oxidising potential. However, it can not digest silicon-containing compounds and release elements bound to this siliceous matrix. For such components, HF is usually added $(10,11)$.

The water-soluble fraction is bioavailable and therefore represents a potentially harmful portion of atmospheric particles. The aim of our study was to compare the concentrations of selected trace elements V, Cr, Mn, Ni, Cu, Zn, As, Cd, Sb, Tl, and $\mathrm{Pb}$ in the water-soluble fraction obtained using two different microwave digestion procedures, one with a mixture of $\mathrm{H}_{2} \mathrm{O}_{2}$ and $\mathrm{HNO}_{3}$ and the other of $\mathrm{HF}, \mathrm{HCl}$, and $\mathrm{HNO}_{3}$. The recoveries of the selected digestion procedures were tested on a certified reference material (NIST SRM 1648 Particulate Matter). The extraction procedures were applied to filters containing $\mathrm{PM}_{10}$ particles collected at an urban background location in Ljubljana.

\section{METHODS}

Sampling of $\mathrm{PM}_{10}$ was performed at an urban background location, Ljubljana-Bežigrad, Slovenia with a reference low volume sampler (Leckel, LVS3) over 24 hours in March and April 2006. Pre-fired quartz filters (Whatman) were used as a sampling substrate. Before the filters were weighed they were conditioned for 48 hours at $20 \pm 1{ }^{\circ} \mathrm{C}$ and $50 \pm 5 \%$ relative humidity.

Filters with deposits were cut into three sub-samples using a punch made of quartz glass. To determine the water-soluble fraction, samples were sonicated in Milli-Q water at room temperature for $30 \mathrm{~min}$. After extraction, the solution was filtered (Sartorious Minisart, pore size $0.2 \mu \mathrm{m}$ ) and acidified with $\mathrm{HNO}_{3}$. All digestions were performed in a microwave oven (Milestone mLs 1200 mega). In the first procedure, a mixture of $\mathrm{HNO}_{3}$ and $\mathrm{H}_{2} \mathrm{O}_{2}$ was applied. The sub sample was placed into a Teflon digestion vessel, and $3 \mathrm{~mL}$ of concentrated $\mathrm{HNO}_{3}, 0.5 \mathrm{~mL}$ of $30 \% \mathrm{H}_{2} \mathrm{O}_{2}$ and $1 \mathrm{~mL}$ of Milli-Q water were added. In the second digestion procedure, a mixture of $\mathrm{HF}, \mathrm{HCl}$, and $\mathrm{HNO}_{3}$ was used. Four millilitres of concentrated $\mathrm{HNO}_{3}, 1 \mathrm{~mL}$ of concentrated $\mathrm{HCl}$, and $1 \mathrm{~mL}$ of $\mathrm{HF}$ were added to the third sub-sample. Before addition, concentrated HF was diluted with Milli-Q water in the ratio 1:4. Digestion was accomplished in two phases. After the first phase, vessels were cooled, and $0.5 \mathrm{~mL}$ of $\mathrm{H}_{3} \mathrm{BO}_{3}$ $\left(40 \mathrm{~g} \mathrm{~L}^{-1}\right)$ was added in order to complex excessive HF. Then the second phase was executed. Conditions for both digestions are described in Tables 1 and 2. After both procedures, samples were diluted with Milli- $Q$ water to $50 \mathrm{~mL}$, filtered through pre-washed filters $\left(20 \mathrm{~mL}\right.$ of $6 \% \mathrm{HNO}_{3}$ ) and the first $20 \mathrm{~mL}$ of filtered sample was withdrawn.

The concentrations of the selected trace metals - V, Cr, Mn, Ni, Cu, Zn, As, Cd, Sb, Tl and Pb were determined by ICP-MS (Agilent 7500ce). Helium was used as the reaction gas in the collision cell, to reduce polyatomic interferences. For measurements, the following $\mathrm{m} / \mathrm{z}$ were selected: ${ }^{51} \mathrm{~V},{ }^{53} \mathrm{Cr},{ }^{55} \mathrm{Mn}$, ${ }^{60} \mathrm{Ni}$, ${ }^{63} \mathrm{Cu},{ }^{66} \mathrm{Zn},{ }^{75} \mathrm{As},{ }^{111} \mathrm{Cd},{ }^{121} \mathrm{Sb},{ }^{205} \mathrm{Tl},{ }^{206} \mathrm{~Pb},{ }^{207} \mathrm{~Pb}$, and ${ }^{208} \mathrm{~Pb}$. For $\mathrm{Pb}$, an average of three mass measurements is given. Elements $\mathrm{Y}, \mathrm{Sc}, \mathrm{Ge}$, and Gd were used as internal standards during the measurement, and before the analysis the signal was optimised using $\mathrm{Li}, \mathrm{Y}, \mathrm{Ce}$, and Ti. 
Table 1 Digestion programme using a mixture of $\mathrm{HNO}_{3}$ and $\mathrm{H}_{2} \mathrm{O}_{2}$

\begin{tabular}{ccc}
\hline & Time / $\min$ & Power / W \\
\hline Step 1 & 2 & 250 \\
Step 2 & 2 & 0 \\
Step 3 & 5 & 250 \\
Step 4 & 4 & 400 \\
Step 5 & 3 & 600 \\
\hline
\end{tabular}

Table 2 Digestion programme using a mixture of $\mathrm{HF}, \mathrm{HCl}$, and $\mathrm{HNO}_{3}$

\begin{tabular}{ccc}
\hline & Time / min & Power / W \\
\hline Phase 1 & & \\
Step 1 & 8 & 250 \\
Step 2 & 5 & 400 \\
Step 3 & 6 & 650 \\
Phase 2 & & \\
Step 1 & 3 & 300 \\
\hline
\end{tabular}

\section{RESULTS AND DISCUSSION}

\section{Recoveries of certified reference material}

The efficiency of both digestion procedures was tested using the certified reference material, NIST SRM 1648, Urban Particulate Matter. Ther results for each element are shown in Table 3. The required recoveries for $\mathrm{Pb}$ and $\mathrm{Cd}$ in SIST EN ISO 14902 (Ambient Air Quality - Standard method for the measurement of $\mathrm{Pb}, \mathrm{Cd}, \mathrm{As}$, and $\mathrm{Ni}$ in the $\mathrm{PM}_{10}$ fraction of suspended particulate matter) are range between $90 \%$ and $110 \%$, while for As and Ni between $85 \%$ and $115 \%$. Recoveries of all four metals by both procedures were in the required ranges. In addition $(100 \pm 15) \%$ recoveries were also achieved for $\mathrm{Mn}$, $\mathrm{Cu}$, and $\mathrm{Zn}$. Lower recoveries were observed for $\mathrm{V}$, $\mathrm{Sb}$, and especially $\mathrm{Cr}(24 \%)$ when using the $\mathrm{HNO}_{3} /$ $\mathrm{H}_{2} \mathrm{O}_{2}$ mixture. The $\mathrm{HF} / \mathrm{HCl} / \mathrm{HNO}_{3}$ mixture yielded more complete digestions, particularly for $\mathrm{Cr}(81 \%)$ and $\mathrm{Sb}$ (increase from the $55 \%$ recovery with the first digestion method to $81 \%$ ).

Problems regarding $\mathrm{Cr}$ characterisation in NIST SRM 1648 are documented in literature. It has been hypothesised that high soot content involves the presence of organic material that inhibits dissolution of $\mathrm{Cr}$ (11). Our results showed that HF not only decomposes silicates, but also enhances the dissolution of $\mathrm{Cr}$ from the organic matrix. The reference material used did not have a certified concentration for Tl. However, Tl concentration determined after decomposition by the mixture of HF, $\mathrm{HCl}$, and $\mathrm{HNO}_{3}$ was significantly higher (3.5 times) than that yielded with the mixture of $\mathrm{HNO}_{3}$ and $\mathrm{H}_{2} \mathrm{O}_{2}$. This difference could probably be attributed to the binding of $\mathrm{Tl}$ to the silica matrix, which is decomposed in the presence of HF.

\section{Concentrations of selected trace elements in ambient particulate matter}

As filters were divided into sub-samples, the homogeneity of the filters was analysed first. All three sub-samples of one filter were digested in a mixture of $\mathrm{HNO}_{3}$ and $\mathrm{H}_{2} \mathrm{O}_{2}$. Relative standard deviations for most of selected elements were lower than $5 \%$, with the exception of $\mathrm{Ni}, \mathrm{Tl}$, and $\mathrm{Pb}$. Higher deviations with $\mathrm{Ni}$ and $\mathrm{Tl}$ can be attributed to their concentrations which were very low, bordering the limit of quantification. The $10 \%$ relative standard deviation for $\mathrm{Pb}$ could be due to non-homogeneity of the filter and/or the deposit.

Figures 1 and 2 show the results from the analysis of selected trace elements in ambient particulate

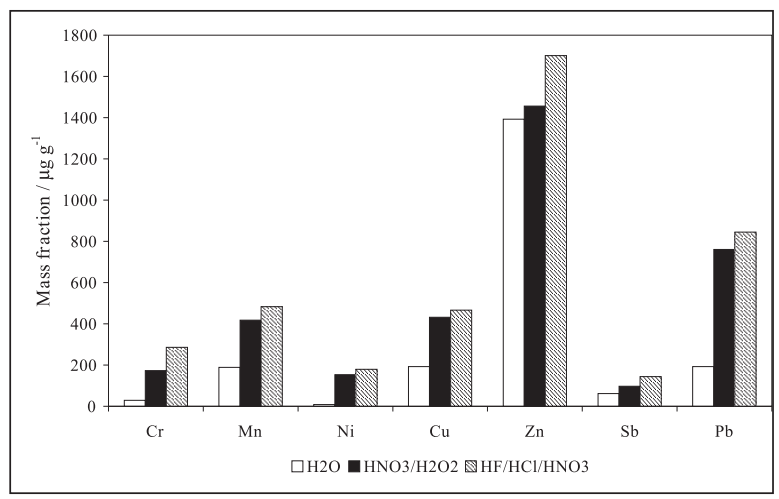

Figure 1 Average mass fractions of $\mathrm{Cr}, \mathrm{Mn}, \mathrm{Ni}, \mathrm{Cu}, \mathrm{Zn}, \mathrm{Sb}$, and $\mathrm{Pb}$ in $P M_{10}$ collected in Ljubljana in the spring of 2005 after different sample preparations - dissolution in water, digestion with $\mathrm{HNO}_{3} / \mathrm{H}_{2} \mathrm{O}_{2}$ and digestion with $\mathrm{HF} / \mathrm{HCl} / \mathrm{HNO}_{3}$

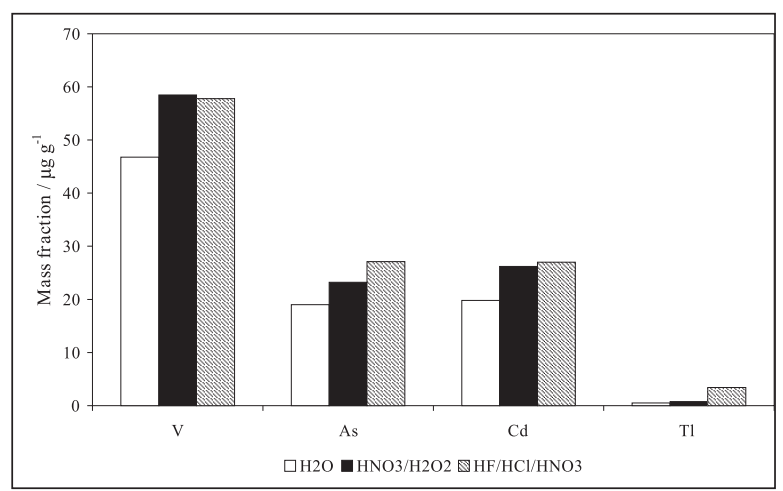

Figure 2 Average mass fractions of $\mathrm{V}, \mathrm{As}, \mathrm{Cd}$, and $\mathrm{Tl}$ in $\mathrm{PM}_{10}$ collected in Ljubljana in the spring of 2005 after different sample preparations - dissolution in water, digestion with $\mathrm{HNO}_{3} \mathrm{H}_{2} \mathrm{O}_{2}$ and digestion with $\mathrm{HF} / \mathrm{HCl} / \mathrm{HNO}_{3}$ 
matter collected in Ljubljana-Bežigrad in the spring of 2006. They show the water-soluble fraction and the fractions after the decomposition by $\mathrm{HNO}_{3} / \mathrm{H}_{2} \mathrm{O}_{2}$ and by $\mathrm{HF} / \mathrm{HCl} / \mathrm{HNO}_{3}$ for these elements. The concentrations obtained after decomposition in the presence of HF can be taken as an approximation for the total concentration. Among the elements analysed, the most water-soluble were $\mathrm{Zn}, \mathrm{As}, \mathrm{V}$, and $\mathrm{Cd}$. For $\mathrm{Zn}$ and $\mathrm{V}$ the water-soluble fraction is about $80 \%$, while for As and $\mathrm{Cd}$ it is about $70 \%$ of the total concentration. $\mathrm{Mn}, \mathrm{Cu}$, and $\mathrm{Sb}$ were moderately soluble in water, with the water-soluble fraction of about $40 \%$ of the total concentration. $\mathrm{Cr}$, $\mathrm{Ni}, \mathrm{Tl}$, and $\mathrm{Pb}$ were almost insoluble in water. Due to significant differences between acid decomposition with and without $\mathrm{HF}$, it can be concluded that $\mathrm{Cr}, \mathrm{Sb}$, and $\mathrm{Tl}$ bind strongly to the matrix of atmospheric particles. However, a comparison with certified material shows a significant difference for $\mathrm{Cr}$. The measured concentration in the reference material in the presence of HF was more than three times higher, while in the urban background aerosol the difference was only 1.7 times. The reason for this could be higher concentration of carbonaceous material in the reference material and also a different matrix of chromium compounds (e.g. silicates). A comparison with a study performed in Edinburgh (6) shows that the ratios of the water-soluble fraction and total concentration for the elements analyzed are very close. In Edinburgh too the most water-soluble elements were $\mathrm{V}, \mathrm{Zn}, \mathrm{As}$, and $\mathrm{Cd}$, with $\mathrm{Mn}, \mathrm{Cu}$ and $\mathrm{Pb}$ being moderately soluble, and $\mathrm{Cr}$ and $\mathrm{Ni}$ almost insoluble.
Figure 3 shows water-soluble and total concentrations (after decomposition by the mixture of $\mathrm{HF}, \mathrm{HCl}$, and $\mathrm{HNO}_{3}$ ) of selected trace elements in $\mathrm{PM}_{10}$ collected in Ljubljana-Bežigrad. Zn displayed the highest concentration within the water-soluble fraction (almost $30 \mathrm{ng} \mathrm{m}^{-3}$ ), with the concentrations of $\mathrm{Cu}, \mathrm{Mn}$ and $\mathrm{Pb}$ in the same fraction in the order of $4 \mathrm{ng} \mathrm{m}^{-3}$. Concentrations of other elements were below $1 \mathrm{ng} \mathrm{m}^{-3}$. A similar behaviour was also observed with total concentrations. The highest total concentration was that of $\mathrm{Zn}$, and was in the range of the water-soluble fraction. The total concentration of $\mathrm{Pb}$ was about $15 \mathrm{ng} \mathrm{m}^{-3}$ (four times higher than in the water-soluble fraction), while concentrations of $\mathrm{Mn}$ and $\mathrm{Cu}$ were in the range of $10 \mathrm{ng} \mathrm{m}^{-3}$. A significant total concentration was also observed for $\mathrm{Cr}$ (about $6 \mathrm{ng} \mathrm{m}^{-3}$ ), and to a lesser extent for $\mathrm{Ni}$ and $\mathrm{Sb}$ (about $3 \mathrm{ng} \mathrm{m}^{-3}$ ). In comparison with other studies performed in Europe $(6,12,13)$, the total concentrations of $\mathrm{V}$,

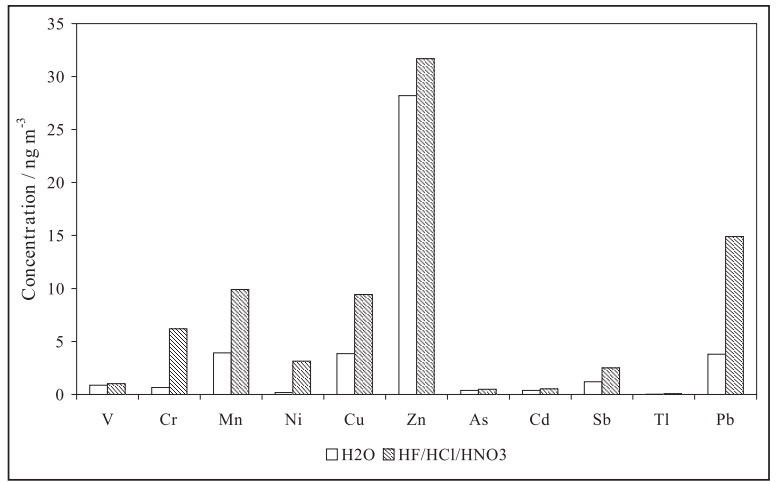

Figure 3 Water-soluble and total (after decomposition performed by mixture of $\mathrm{HF}, \mathrm{HCl}$ and $\mathrm{HNO}$ ) concentrations of selected trace elements in $\mathrm{PM}_{10}$ collected in Ljubljana-Bežigrad

Table 3 Results of both digestion methods for certified reference material (NIST SRM 1648, Urban Particulate Matter). 1) Digestion with a mixture of $\mathrm{HNO}_{3}$ and $\mathrm{H}_{2} \mathrm{O}_{2}$; 2) Digestion with a mixture of $\mathrm{HF}, \mathrm{HCl}$, and $\mathrm{HNO}_{3}$

\begin{tabular}{lccccc}
\hline Element & $\begin{array}{c}\text { Certified value / } \\
\mu \mathbf{g ~ g}^{-1}\end{array}$ & $\begin{array}{c}\text { Measured value 1 / } \\
\mu \mathbf{g ~ g}^{-1}\end{array}$ & $\begin{array}{c}\text { Recovery 1 / } \\
\%\end{array}$ & $\begin{array}{c}\text { Measured value 2 / } \\
\mu \mathbf{g ~ g}^{-1}\end{array}$ & $\begin{array}{c}\text { Recovery 2 / } \\
\%\end{array}$ \\
\hline $\mathrm{V}$ & $127 \pm 7$ & 106 & 83 & 111 & 87 \\
$\mathrm{Cr}$ & $403 \pm 12$ & 98 & 24 & 320 & 81 \\
$\mathrm{Mn}$ & $786 \pm 17$ & 743 & 93 & 770 & 97 \\
$\mathrm{Ni}$ & $82 \pm 3$ & 72 & 88 & 75 & 91 \\
$\mathrm{Cu}$ & $609 \pm 27$ & 569 & 93 & 540 & 88 \\
$\mathrm{Zn}$ & $4760 \pm 140$ & 4567 & 96 & 4370 & 92 \\
$\mathrm{As}$ & $115 \pm 10$ & 123 & 107 & 109 & 95 \\
$\mathrm{Cd}$ & $75 \pm 7$ & 76 & 102 & 67 & 90 \\
$\mathrm{Sb}$ & 45 & 25 & 55 & 36 & 81 \\
$\mathrm{Tl}$ & $/$ & 2 & $/$ & 7 & $/$ \\
$\mathrm{Pb}$ & $6550 \pm 80$ & 6269 & 96 & 6270 & 96 \\
\hline
\end{tabular}


$\mathrm{Ni}, \mathrm{As}, \mathrm{Cd}$, and $\mathrm{Pb}$ in Ljubljana are comparable to the concentrations measured at urban locations in Edinburgh and Vienna. Concentrations of $\mathrm{Cu}$ and Zn are about two times higher in Ljubljana. However, the most pronounced differences were observed for $\mathrm{Cr}$ and $\mathrm{Mn}$, with concentrations four times higher in Ljubljana. This could not only be due to possible differences between the particle composition between the different regions, but also due to the sample preparation method used. In both studies the decomposition of the sample deposits was not done in the presence of HF (Vienna study: only extraction with concentrated $\mathrm{HNO}_{3}$, Edinburgh study: hot extraction by a mixture of $\mathrm{HCl}$ and $\mathrm{HNO}_{3}$ ) and therefore $\mathrm{Cr}$ and $\mathrm{Mn}$ bound to the silicate matrix were not released into the solution. The studies performed in Milan, Italy and Łodz, Poland (12) showed that concentrations of practically all analysed elements in these two cities were about an order of magnitude higher than in Ljubljana, Edinburgh, and Vienna.

\section{CONCLUSION}

Since the water-soluble fraction is bioavailable and therefore a potentially harmful portion of atmospheric particles, our study focused on the determination of this fraction of selected trace elements and on comparison of two different microwave digestion procedures used to determine them: one using a mixture of $\mathrm{H}_{2} \mathrm{O}_{2}$ and $\mathrm{HNO}_{3}$ and the other a mixture of $\mathrm{HF}, \mathrm{HCl}$, and $\mathrm{HNO}_{3}$.

Analysis of a certified reference material showed that both digestion procedures met the requirements of the SIST EN ISO 14902 for Pb, As, Cd and Ni. Recoveries of $100 \pm 15 \%$ were also achieved for $\mathrm{Mn}$, $\mathrm{Cu}$ and $\mathrm{Zn}$. Very low recoveries of $\mathrm{Cr}$, Sb, and $\mathrm{V}$ were obtained with the $\mathrm{HNO}_{3} / \mathrm{H}_{2} \mathrm{O}_{2}$ mixture, while the $\mathrm{HF} /$ $\mathrm{HCl} / \mathrm{HNO}_{3}$ mixture yielded generally better recoveries particularly for $\mathrm{Cr}$ and $\mathrm{Sb}$.

$\mathrm{Zn}, \mathrm{Cu}, \mathrm{Mn}$, and $\mathrm{Pb}$ in the $\mathrm{PM}_{10}$ samples collected in Ljubljana showed the highest concentrations in the water-soluble fraction, while $\mathrm{Tl}, \mathrm{Ni}, \mathrm{As}$, and $\mathrm{Cd}$ showed the lowest. A comparison between the two applied digestion procedures has shown that $\mathrm{Cr}$, $\mathrm{Ni}$, $\mathrm{Sb}, \mathrm{Pb}$, and $\mathrm{Tl}$ bind strongly to the sample matrix. Total concentrations of the analysed elements were similar to concentrations obtained in Edinburgh and Vienna, while concentrations of most elements measured in Milan and Łodz were higher by about one order of magnitude.

\section{Acknowledgement}

This work was supported by the Slovenian Research Agency (Contract No. P1-0034-0104) and was done in the frame of COST-633 Action.

\section{REFERENCES}

1. Mészáros E. Fundamentals of atmospheric aerosol chemistry. Budapest: Akadémiai Kiadó; 1999.

2. Dockery DW, Pope CA, Xu XP, Spenger JD, Ware JH, Fay ME, Ferris BG, Speizer FE. An association between air-pollution and mortality in 6 United-states cities. New Eng J Med 1993;329:1753-9.

3. Seinfield JH, Pandis SN. Atmospheric chemistry and physics. From air pollution to climate change. New York: John Wiley \& Sons; 1998.

4. McMurry PH. A review of atmospheric aerosol measurements. Atmos Environ 2000;34:1959-99.

5. Pruppacher HR, Klett JD. Microphysics of clouds and precipitation. Dordecht: Kluwer Academic Publishers; 1997.

6. Heal MR, Hibbs LR, Agius RM, Beverland IJ. Total and water-soluble trace metal content of urban background PM10, PM2.5 and black smoke in Edinburgh, UK. Atoms Environ 2005;39:1417-30.

7. Hext PM, Rogers KO, Paddle GM. The health effects of PM2.5 (including ultrafine particles). CONCAWE report no. 99/60, Brussels, November 1999.

8. Allen AG, Nemitz E, Shi JP, Harrison RM, Greenwood JC. Size distribution of trace metals in atmospheric aerosols in the United Kingdom. Atoms Environ 2001;35:4581-91.

9. Okuda T, Kato J, Mori J, Tenmoku M, Suda Y, Tanaka S, He K, Ma Y, Yang F, Yu X, Duan F, Lei Y. Daily concentrations of trace metals in aerosols in Beijing, China, determined by using inductively coupled mass spectrometry equipped with laser ablation analysis, and source identification of aerosols. Sci Total Environ 2004;330:145-58.

10. Yang KX, Swami K, Husain L. Determination of trace metals in atmospheric aerosols with heavy matrix of cellulose by microwave digestion-inductively coupled plasma mass spectroscopy. Spectrochim Acta Part B 2002;57:73-84.

11. Pekney NJ, Davidson Cl. Determination of trace elements in ambient aerosol samples. Anal Chim Acta 2005;540:269-77.

12. Bem H, Gallorini M, Rizzo E, Krzemińska M. Comparative studies on the concentrations of some elements in the urban air particulate matter in Lodz City of Poland and in Milan, Italy. Environ Int 2003;29:423-8.

13. Puxbaum H, Gomiscek B, Kalina M, Bauer H, Salam A, Stopper S, Prening O, Hauck H. A dual study of PM2.5 and PM10 aerosol chemistry in the larger region of Vienna, Austria. Atoms Environ 2004;38:3949-58. 


\section{Izuleček}

\section{DOLOČEVANJE NEKATERIH ELEMENTOV V SLEDOVIH V ATMOSFERSKIH DELCIH}

Določevanje elementov v sledovih v atmosferskih delcih je pomembno zaradi njihovega toksičnega vpliva na človekovo zdravje. V zadnjem času se koncentracije teh elementov tudi zelo pogosto uporabljajo $\mathrm{v}$ študijah povezanih s porazdelitvijo po virih. Za določevanje elementov v sledovih se uporabljajo različne priprave vzorcev. Najpogostejši je razklop filtrov s pomočjo mikrovalovne peči. Ker je vodotopen delež tudi biološko dostopen, je bil namen naše študije določitev te frakcije posameznih elementov ( $\mathrm{V}, \mathrm{Cr}, \mathrm{Mn}, \mathrm{Ni}, \mathrm{Cu}$, $\mathrm{Zn}, \mathrm{As}, \mathrm{Cd}, \mathrm{Sb}, \mathrm{Tl}$ and $\mathrm{Pb}$ ) in primerjava s koncentracijami po dveh različnih razklopih - prvi z mešanico $\mathrm{H}_{2} \mathrm{O}_{2}$ in $\mathrm{HNO}_{3}$ ter drugi z mešanico $\mathrm{HF}, \mathrm{HCl}$ in $\mathrm{HNO}_{3}$. Izkoristke uporabljenih razklopov smo preverili s standardnim referenčnim materialom (NIST SRM 1648 Urban Particulate Matter). Preverjena postopka smo uporabili na filtrih, ki so vsebovali delce PM10, vzorčevane v Ljubljani, Slovenija. Med analiziranimi elementi so bili izrazito dobro topni v vodi V, Zn, As in Cd, najmanj pa $\mathrm{Cr}$, Ni, Tl, in Pb. Primerjava med obema uporabljenima razklopoma je pokazala, da so $\mathrm{Cr}$, Ni, Sb in $\mathrm{Tl}$ v delce izredno stabilno vezani.

KLJUČNE BESEDE: ICP-MS, kemijska analiza, kovine, PM10, razklop, urbani aerosoli, vodotopni delež

\section{CORRESPONDING AUTHOR:}

Janja Turšič

Environmental Agency of the Republic of Slovenia

Vojkova 1b, SI-1000 Ljubljana, Slovenia

E-mail:janja.tursic@gov.si 